\title{
A CLIMATIC RECORD USING AN ICE CORE FROM THE TRANSANTARCTIC MOUNTAINS, ANTARCTICA \\ (Abstract)
}

by

Paul A. Mayewski, W. Berry Lyons, M.J. Spencer and Mark S. Twickler

(Glacier Research Group and Earth Science Department,

University of New Hampshire, Durham, NH 03824, U.S.A.)

and

Pieter M. Grootes and Minze Stuiver

(Quaternary Isotope Laboratory, University of Washington, WA 98195, U.S.A.)

The production of climatic-change records using glaciochemical time series has seen minimal application in the Transantarctic Mountains. This is true despite the fact that glacial geologic studies in this area are the primary basis for understanding the glacial history of East Antarctica and thus provide an excellent potential framework for the more detailed records obtainable from glaciochemical studies. Numerous sites within the Transantarctic Mountains fit the requirements necessary for the retrieval of ice cores, and pilot studies have been conducted in both southern Victoria Land (Mayewski and Lyons 1982) and northern Victoria Land (Allen and others 1985). These pilot studies have validated the hypothesis that glaciochemical records retrieved from appropriately chosen ice-core sites in the Transantarctic Mountains can be used for: (1) assessing the current stability of the East Antarctic ice sheet, (2) validating models concerning the recent glacial history of the Transantarctic Mountains, (3) searching for relatively high-frequency (1-100 year) climatic signals, (4) determining changes in the relative geography (ocean-land-ice) of a region, and (5) defining the relative importance of the chemical species source areas (i.e. volcanic, biogenic, anthropogenic, marine, crustal) that provide precipitation to the Transantarctic Mountains.

During the 1984-85 austral summer, a combined University of New Hampshire-Polar Ice Coring Office effort resulted in the recovery of a $201 \mathrm{~m}$ long core from a $2800 \mathrm{~m}$ high snow massif atop the Dominion Range $\left(85^{\circ} 15^{\prime} \mathrm{S}, 166^{\circ} 10^{\prime} \mathrm{E}\right)$, close to the confluence of the Mill and Beardmore glaciers. Chemical and physical data sets to be developed from this ice core, which is estimated to span a period of approximately 1000 years, include: a detailed $6 \mathrm{~m}$ snow pit, several shallow snow pits, and fresh and aged surface snow, in combination with a radio echo-sounding survey of the general area, which will be used to provide three-dimensional control. Chemical and physical analyses conducted as part of the study include: stratigraphy, density, sulfate, nitrate, fluoride, chloride, phosphate, sodium, reactive silicate, total beta activity and oxygen isotopes. The oxygen-isotope analyses are being provided by P. Grootes and M. Stuiver (University of Washington), and all other analyses are being conducted by the Glacier Research Group (University of New Hampshire).

To date, only the $6 \mathrm{~m}$ snow pit has been analyzed in detail, to assess the possibility of using the chemical species selected for this study as seasonal and air-mass source indicators. Timing of the chemical species input in the $6 \mathrm{~m}$ snow pit record is currently being calibrated, using total beta activity and oxygen-isotope measurements. It appears that nitrate, chloride and sulfate provide indentifiable seasonal signals. In addition, source identification for these chemical species, as well as the others studied, appears to be useful in developing proxy records of climatic change.

Analysis of the $201 \mathrm{~m}$ core is currently under way.

This research is supported by the National Science Foundation Division of Polar Programs.

\section{REFERENCES}

Allen III B, Mayewski P A, Lyons W B, Spencer M J 1985 Glaciochemical studies and estimated net mass balances for Rennick Glacier area, Antarctica. Annals of Glaciology 7: 1-6

Mayewski P A, Lyons W B 1982 Source and climatic implication of the reactive iron and reactive silicate concentration found in a core from Meserve Glacier, Antarctica. Geophysical Research Letters 9(3): 190-192 